\title{
REVOLUTIONARY SYNDICALISM IN THE ITALIAN LABOR MOVEMENT: THE AGRARIAN STRIKES OF 1907-08 IN THE PROVINCE OF PARMA
}

In the decade before World War I, revolutionary syndicalists and reformist socialists clashed repeatedly in the Italian labor movement. The reformist socialists, who maintained a hegemony throughout this period, advocated cooperation and compromises with the bourgeoisie and the government, supported by the Socialist Party in Parliament, to secure socio-economic benefits for the workers. The revolutionary syndicalists, who began to present an alternative to this strategy in 1905, favored direct action by workers through the unions to seize advantages from the bourgeoisie and reinforce the class consciousness of the proletariat. ${ }^{1}$ They asserted that the strike was the most effective means to win socio-economic reforms and bring about changes in politics. At the same time, they believed that it attracted converts and strengthened the union movement. ${ }^{2}$ The revolutionary syndicalists also argued that striking workers acquired initiative and combativeness, sentiments of unity and solidarity, and developed a heroic ethos of duty, dedication and sacrifice ${ }^{3}$ The challenge of a strike, on the other hand, restored energy to the bourgeoisie: it transformed the property owners into aggressive, worthy opponents of the proletariat. ${ }^{4}$ As illusions of collaboration disappeared in the heat of battle, the revolutionary syndicalists predicted that the struggle between the proletariat and the bourgeoisie would become more intense and intransigent. ${ }^{5}$

1 Enrico Leone, Il sindacalismo (Milan, 1907), pp. 8-9; Arturo Labriola, "Gli eccidi proletari e la decomposizione del PSI", in : Pagine Libere, II (1908), p. 448. 2 S[ergio] Panunzio, "Il momento critico del socialismo", in: Pagine Libere, II, pp. 226-27.

3 Paolo Orano, "I risultati di un grande sciopero", in: La Cultura Socialista (Rome), I (1908), pp. 137-40; L'Internazionale, May 30, 1908; Lotta Socialista (Genoa), June 14, 1908.

4 Georges Sorel to Paolo Orano, August 16, 1908, in: Paolo Orano, Il fascismo, I, Vigilia sindacalista dello stato corporativo (Rome, 1939), p. 86.

5 Georges Sorel, Lo sciopero generale e la violenza, Preface by Enrico Leone (Rome, 1906), pp. 64, 67-69. 
After the reformists won a majority at the constituent congress of the General Confederation of Labor (CGL) in 1906, the revolutionary syndicalists decided to concentrate on activities in the base of the union movement. They achieved the most notable success among the day laborers of Emilia-Romagna in the Po Valley. Throughout the pre-war era, their stronghold was the chamber of labor in the province of Parma. Organizing all the union members in an area, usually a province, the chamber of labor was a key organization for Italian workers. Mediating economic rivalries and attenuating political differences among its heterogeneous membership, it contributed to develop a solidarity that extended beyond the category to the working class. Conceived as an employment agency with an ample range of services - such as the collection of statistics, arbitration commissions, circulating libraries, night schools, legal and medical aid - within a short time, it began negotiating job contracts and leading strikes. Its composite membership and diverse activities gave the chamber of labor a broad perspective. It tended, therefore, to defend and advance the workers' interests in many different areas. ${ }^{1}$ The revolutionary syndicalists, who appreciated these characteristics, envisaged the chamber of labor as the focus of working-class action in the capitalist society, the instrument of a proletarian revolution, and the nucleus of a socialist society. ${ }^{2}$

By analyzing two agrarian strikes that the revolutionary syndicalists in the Parmesan chamber of labor led in 1907-08, this study identifies their strategy, tactics and objectives in the unions of the countryside. It aims, in addition, to ascertain the impact of the revolutionarysyndicalist current in the province of Parma: it examines the composition and combativeness of the striking categories; the attitude of the reformist socialists in the labor movement and the Socialist Party (PSI); the resistance of the landowners to the demands of the chamber of labor; and the actions of the government authorities in these agitations. Focusing on the working-class base, this type of analysis is the most effective method to determine the significance of revolutionary syndicalism in the Italian labor movement before World War I. ${ }^{3}$

1 Renato Brocchi, L'organizzazione di resistenza in Italia (Macerata, 1907), p. CXXXIII.

${ }_{2}$ Arturo Labriola, Riforme e rivoluzione sociale (Milan, 1904), pp. 2, 4-5, 14, $30-31,35,116,216-17$.

${ }^{3}$ As part of my research for a book on Italian revolutionary syndicalism, I have been investigating its provincial organizations in Emilia-Romagna, Lombardy, Liguria, Piedmont, and Tuscany. On the province of Ferrara, see Alessandro Roveri, Dal sindacalismo rivoluzionario al fascismo: Capitalismo agrario e socialismo nel ferrarese (1870-1920) (Florence, 1972). For the province of Parma, 
The nature of the working class explains much about the revolutionary syndicalists' success in the province of Parma. Although the proportion of people in industry increased from 17.5 per cent in 1901 to 20.6 per cent of the labor force in 1911, the majority were working in alimentary enterprises, construction and woodworking, textile mills, garment trades and tanneries. Since these sectors employed many women and children, without a strong class consciousness, the proportion of union members was low. In this economy, agriculture still played the leading role. The slight decline of people in agriculture from 66.9 per cent in 1901 to 62.3 per cent of the labor force in 1911 was not affecting this predominance. ${ }^{1}$ The main crops were wheat, corn, grapes, tomatoes, and the breeding of cattle and hogs. On the plain there were large, modern farms worked by day laborers and salaried workers; in the southern hills, small proprietors, tenant farmers and sharecroppers were more common. ${ }^{2}$ During this decade, the expansion of capitalistic

see Biagio Riguzzi, Sindacalismo e riformismo nel parmense (Bari, 1931); Pier Luigi Spaggiari, "Il sindacalismo rivoluzionario a Parma: Lo sciopero delle bustaie del 1907", in: Aurea Parma, LIII (1969), pp. 3-49; Paolo Basevi, "Lo sciopero agrario a Parma nel 1908", in: Emilia, III (1951), pp. 144-47; and Mario De Micheli, Barricate a Parma (Rome, 1960). For the province of Modena, emphasizing the activities of one of the revolutionary-syndicalist labor organizers, see Alceo Riosa, "Ottavio Dinale e le lotte agrarie nel modenese (1901-1906)", in: Nuova Rivista Storica, LII (1969), pp. 677-705. The article by Pietro Bolchini, "Milano 1915: Il socialismo e la guerra", in: Movimento Operaio e Socialista, XVI (1970), pp. 261-91, contains some information on the Unione Sindacale Milanese, headed by Filippo Corridoni, in 1913-15. Gaetano Perillo mentions the revolutionary-syndicalist movement in Liguria in "Socialismo e classe operaia nel genovesato dallo sciopero del 1900 alla scissione sindacalista", in: Il Movimento Operaio e Socialista in Liguria, VI (1960), pp. 155-79, and VII (1961), pp. 37-56. For the revolutionary syndicalists' activities in the Turin metallurgical workers' strike of 1912, see Paolo Spriano, Socialismo e classe operaia a Torino dal 1892 al 1913 (Turin, 1958), pp. 273-81. On the revolutionary-syndicalist movement in Piombino and on the Island of Elba, see Giovanni Francovich, "Lo sciopero generale del 1911 alle acciaierie di Piombino", in: Rivista Storica del Socialismo, IX (1966), pp. 126-48; and Paolo Favilli, Capitalismo e classe operaia a Piombino: 1861-1918 (Rome, 1974), pp. 164-226. 1 Ministero di Agricoltura, Industria e Commercio, Direzione Generale di Statistica, Censimento della popolazione del Regno d'Italia al 10 febbraio, 1901, III (Rome, 1904), pp. 430-83; Ministero di Agricoltura, Industria e Commercio, Direzione Generale della Statistica e del Lavoro, Ufficio del Censimento, Censimento della popolazione del Regno d'Italia al 10 giugno, 1911, IV (Rome, 1915), pp. 552-53. The statistics for 1901 included everyone nine years of age and above. The statistics for 1911 included everyone ten years of age and above. ${ }^{2}$ Camera di Commercio ed Arti di Parma, Relazione sull'andamento delle industrie e del commercio del distretto durante il 1908 (Parma, 1909), pp. 7-11, 21-24. 
agriculture was bringing about significant changes in the countryside. It meant the extension of land reclamation and irrigation projects; the introduction of machinery, scientific methods of production and industrial crops, such as hemp, tomatoes and sugar beets; and the consolidation of subsistence plots into large estates. ${ }^{1}$

One consequence of this modernization was substantial shifts of population in agriculture from 1901 to 1911 . The number of people in the landowning category, which included many peasant proprietors, decreased from 30,656 to 23,222 . Some small holders, forced to sell their land, might have become tenant farmers: the number of people in this category increased from 7,370 to 8,767 in ten years. Since sharecropping was an inefficient system of production, it is not surprising that the sharecroppers in the province decreased from 22,745 to 18,609 . The salaried workers, who had annual contracts, which often included living quarters and participation in profit-sharing plans, decreased from 17,996 to 9,285 . It made more economic sense, in fact, to hire day laborers when necessary. Absorbing many peasant proprietors, sharecroppers and salaried workers, the day laborers increased from 22,593 to 41,265 in the decade. ${ }^{2}$ The day laborers in capitalistic agriculture, who had broken with the traditions of the peasant cosmos, were becoming the homogeneous, combative vanguard of the working class in the countryside of the Po Valley. ${ }^{3}$ Desperate men, with little to lose, they were usually in the forefront of most agitations and strikes in agriculture. By 1906-07, chronic unemployment and a high rate of inflation were causing considerable discontent among the day laborers in the province of Parma. ${ }^{4}$ Faced with mounting criticism, the ineffective, moderate secretary of the chamber of labor submitted his resignation.

On February 10, 1907, Alceste De Ambris, an aggressive revolutionary syndicalist, became secretary of the chamber of labor. With energy, a genius for propaganda and organization, and an authentic charisma, this man moved at once to regenerate the labor movement and trans-

${ }^{1}$ Shepard B. Clough, The Economic History of Modern Italy (New York, 1964), pp. 103-11; Gioacch no Volpe, Italia moderna, II (Florence, 1973), pp. 138-39, 142-53, 279-82; Karl Kautsky, La questione agraria, Introduction by Giuliano Procacci (Milan, 1959), pp. 44-67, 72, 104, 110.

2 Censimento 1901, op. cit., III, pp. 430-31; Censimento 1911, op. cit., IV, p. 524.

Emilio Sereni, II capitalismo nella campagna: 1860-1900 (Turin, 1968), pp. 340-43; Arrigo Serpieri, Studi sui contratti agrari (Bologna, 1920), pp. 140-41; Giuseppe Medici and Giuseppe Orlando, Agricoltura e disoccupazione: I braccianti della bassa pianura padana (Bologna, 1952), pp. 74-76.

4 In 1906-07, the wage of a day laborer, depending on sex, age and place of work, was 8-20 centesimi per hour; the price of bread was circa 50 centesimi per kilo. Basevi, "Lo sciopero agrario", loc. cit., p. 144. 


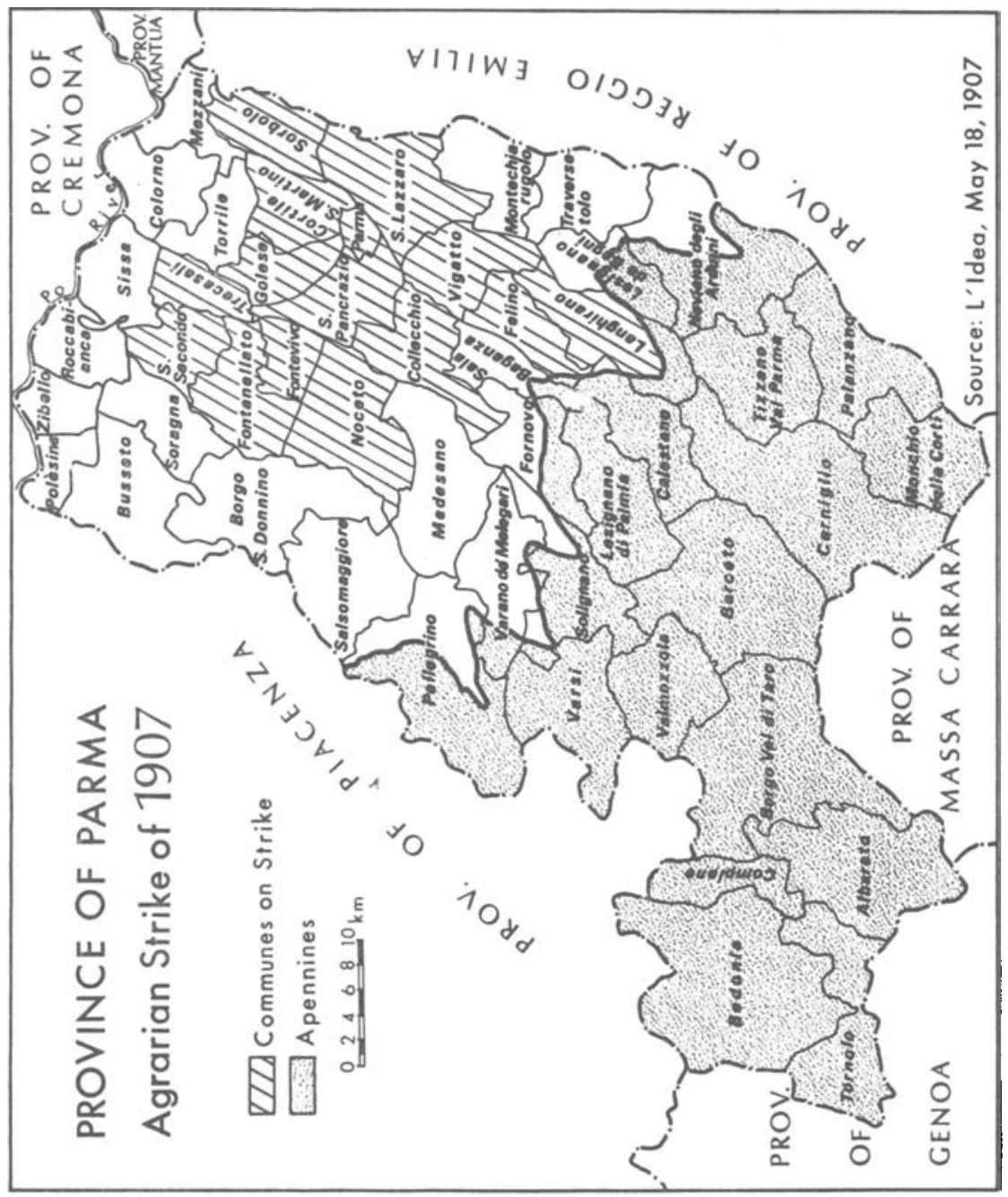

form the province of Parma into a bastion of revolutionary syndicalism. ${ }^{1}$ Issuing a challenge to the landowners, a congress of agricultural workers met the next month and approved a program of minimum wages and maximum hours for the province. It also recommended establishing union employment offices to assist salaried workers and

1 La Protesta (Parma), October 18, 1913. See also L'Avanguardia (Parma), March 4, 1909; and Archivo Centrale dello Stato, Rome, Ministero dell'Interno, Direzione Generale di Pubblica Sicurezza, Casellario Politico Centrale, "Alceste De Ambris", 
sharecroppers to find jobs and negotiate contracts. ${ }^{1}$ The landowners, unaccustomed to a dialogue with the unions, made no attempt to discuss these issues. Preparing to resist the workers' demands, they initiated a campaign to increase the membership of the Parmesan Agrarian Association (AAP). Designed to protect and further the interests of the landowning class, this organization was assuming a leading role in the struggle against the pretensions of the revolutionary syndicalists in the chamber of labor.

Reacting to this intransigence, the chamber of labor declared a strike of day laborers and salaried workers, including stable hands, on May 15, 1907. Although it permitted the sharecroppers to continue working, it warned them to avoid any activities that might damage the agitation. ${ }^{2}$ Extending to fourteen communes in the plain around the city of Parma, this strike made a single contract possible and eliminated the great diversity in wages and hours that the proprietors had used in the past to sow discord among the workers. ${ }^{3}$ The abandonment of 60,000 head of cattle by the stable hands, without precedent in the province, meant that the workers were determined to win at any cost. It was this action that brought the proprietors to agree to a settlement. ${ }^{4}$ Through the mediation of the prefect, assisted by the mayor of Parma, discussions between the two parties had opened within two days of the outbreak of the strike. Since there were not any serious snags, they signed a three-year contract on May 21, which satisfied a large proportion of the strikers' demands on wages and hours (there was no mention of union employment offices)..$^{5}$ The workers had won.

The landowners, however, were eager for revenge and determined to oppose the workers' claims in the future. To hold down costs, they began limiting the employment of day laborers. Some reduced work to the most necessary tasks or made more use of machinery. Small landowners, tenant farmers and sharecroppers prolonged their working days or exchanged labor with neighbors. ${ }^{6}$ The working-class press in the province charged that a "little reaction" was underway to discriminate against union activists and discredit the chamber of labor. It saw the same design in the sentences that the courts were handing

1 L'Idea, April 7, 1907.

${ }^{2}$ Ibid., May 18, 1907.

3 Bollettino dell'Associazione Agraria Parmense (AAP), September 10, 1907.

- Atti del Parlamento Italiano, Camera dei Deputati, Sessione 1904-07, Discussioni, Tornata del 3 giugno, 1907, XII (Rome, 1907), pp. 15162-63.

5 Avanti!, May 22, 1907.

- Francesco Fontana, Lo sciopero agrario nel parmense: Cause, vicende, rimedi (Parma, 1908), p. 13. 
down to strikers arrested for violating the right to work in the recent agitation. ${ }^{1}$ The proprietors rebutted that the workers had initiated boycotts in some communes to force the discharge of non-union men, and that the day laborers were taking advantage of heavy demand for hands at the harvest to ask for wages in excess of the contract. ${ }^{2}$ Meanwhile, the AAP, led by Lino Carrara, a combative, resolute adversary of the unions, was becoming one of the strongest landowners' organizations in the nation with circa 3,000 members. ${ }^{3}$ Giving a vivid picture of sentiments among the landowners, its bulletin wrote:

“The drops of poison are dripping slowly into the workers' minds: this propaganda has created the profound conviction that the workers are victims of an odious exploitation. It has depicted the men who invest capital in farms, seeking to augment, with the prosperity of agriculture, the general welfare, as filthy vampires. The proprietor is no longer the comrade of the working hours, the mind that directs and advises for the common good. He is now a ferocious and gloomy enemy, who speculates in misery and brutishness."4

The AAP's strategy was to hit the leadership of the unions, responsible for "the permanent agitation, the continuous menace of strikes, the boycotts, [...] the employment offices", which were beginning "to give enormous annoyance and irritation to the landowning class, so that it intends to proclaim loudly: enough!"5

Besides the great agrarian strike of May 15-21, the workers claimed victories in thirty-three minor agitations in agriculture and industry in 1907. The year had been a success for the unions of the province. In the working class there was a widespread conviction that an epoch of confrontation between capital and labor was beginning. It faced the challenge with confidence. The most notable evidence of this progress and optimism was the increase in the membership of the chamber of labor from 13,446 on January 1,1907 to 28,719 on January $1,1908 .^{6}$ Reporting to the congress of the chamber of labor on October 19-20, 1907, the secretary gave this breakdown:

1 L'Idea, July 20, 1907.

2 Bollettino AAP, April 18, 1908.

3 Basevi, "Lo sciopero agrario", p. 144.

- Bollettino AAP, August 24, 1907.

5 Ibid., September 10, 1907.

- Ministero di Agricoltura, Industria e Commercio, Supplemento al Bollettino dell'Ufficio del Lavoro, No 20, Statistica delle organizzazioni di lavoratori al 1 gennaio, 1913 (Rome, 1914), p. 104; L'Idea, November 16, 1907. 
Membership of the Chamber of Labor in Parma, October 1907

$\begin{array}{lr}\text { Category } & \text { Membership } \\ \text { Agriculture } & \\ \text { Day laborers (male) } & 10,065 \\ \text { Day laborers (female) } & 7,617 \\ \text { Salaried workers } & 2,096 \\ \text { Sharecroppers } & 1,157 \\ \text { Small proprietors and tenant farmers } & 91 \\ \text { Alimentary } & 666 \\ \text { Construction and woodworking } & 2,973 \\ \text { Metallurgy and glass } & 489 \\ \text { Garment trades } & 1,439 \\ \text { Transport and public services } & 1,414 \\ \text { Miscellaneous } & 106 \\ \text { Cooperatives and mutual-aid societies } & 1,318 \\ \text { Total } & 29,431\end{array}$

Source: L'Idea, October 26, 1907

These data demonstrate the preponderance of agricultural workers - above all day laborers - in the unions. Even in non-agricultural occupations, there were only 3,819 workers in urban areas; the statistics classified the remaining 3,268 as "industrial workers in the countryside". 1 They were most likely workers in the alımentary and construction industries, who had close ties of kinship and interest with their brethren in agriculture.

At this congress, the delegates approved setting up a single treasury in the chamber of labor. Replacing the treasuries of some two-hundred local unions, it was designed to give the chamber of labor the financial independence to guarantee its freedom of initiative. ${ }^{2}$ The proponents of this system argued that thenceforth they would not be obliged to maintain contacts with political parties in order to get subsidies from the commune. ${ }^{3}$ The single treasury gave the chamber of labor access to a considerable amount of money. It seems to be one explanation of the organization's success in winning a large number of strikes in this period.

1 L'Idea, October 26, 1907.

2 Ibid.

3 Tullio Masotti, La pratica sindacalista: Commento critico all'azione svolta dalla camera del lavoro di Parma (Parma, 1910), pp. 17-18. See also La Scintilla (Ferrara), December 22, 1912. 
Despite the successes, however, some opposition was developing among reformist socialists in the unions of the province. They intended to resist the revolutionary syndicalists' attempts "to open up here also a violent struggle" against the CGL and PSI. ${ }^{1}$ In February 1908, the reformists formed a chamber of labor in the commune of Borgo San Donnino (today, Fidenza), which claimed a membership of 5,000 workers. ${ }^{2}$ Since a chamber of labor had existed in Borgo San Donnino in the past, provincial rivalries played a role in creating the new one. ${ }^{3}$ It also seems that socio-economic conditions in this part of the plain, where there were many sharecroppers, were better than elsewhere in the province. ${ }^{4}$ These workers preferred to cooperate with the bourgeoisie and adopt a moderate line of action in labor agitations. Although the reformists had genuine grievances and sincere motives for abandoning the chamber of labor, their secession was inopportune. It must have encouraged the proprietors, anxious to smash the unions, to persevere in their intention to fight a decisive battle in the spring of 1908.

\section{II}

The ostensible cause of the great agrarian strike of 1908 was a disagreement about some clauses in the contract of $1907 .^{5}$ To settle the controversy, the AAP had offered as early as August 9, 1907, to submit the differences to an arbitration commission as provided for in the contract. Replying four days later, the chamber of labor refused to nominate its representatives. ${ }^{6}$ Although the revolutionary syndicalists had accepted mediation and arbitration in the past, they must have had enough confidence on this occasion to reject any compromise with the strategy of direct action. There was, in addition, a strong

1 L'Idea, November 30, 1907.

2 Ibid., April 25, 1908.

${ }^{3}$ Ibid., February 29, 1908.

4 De Micheli, Barricate a Parma, p. 38.

${ }^{5}$ The landowners maintained that salaried workers without care of livestock had an obligation to work the same thirteen-hour day as salaried workers with livestock, since they received the same pay; the chamber of labor argued that the former should work a ten-hour day like the day laborers. The landowners claimed that they had the right to subtract 60 lire of house rent from the 600 lire annual salary of every salaried worker in a family; the chamber of labor wished the rent to be 60 lire per family, irrespective of the number of salaried workers in it. The landowners insisted that female salaried workers, whose pay and hours were fixed in the contract, had an obligation to work when the proprietor requested their services; the chamber of labor rebutted that the women had the right to refuse. O. Bagatti, "La lotta economica nel parmense", in: Rivista Popolare di Politica, Lettere e Scienze Sociali, XIV (1908), pp. 234-35.

B Bollettino AAP, April 8, 1908. 
desire in the unions to take up the proprietors' challenge. ${ }^{1}$ It is also important to understand that both parties were using the contrasts on wages and hours to justify a well-nigh inevitable battle; in less tense circumstances, such differences would not have prevented a resolution of the controversy.

After the defeats of 1907 , the landowners did not really want to come to terms with the chamber of labor. They intended to crush the unions. To this end, the AAP promoted the organization of an InterProvincial Federation of Landowners, covering the provinces of Parma, Bologna, Ferrara, Ravenna and Piacenza in Emilia-Romagna, plus Vercelli and Novara in Piedmont, on December 15, 1907. They intended to seek in themselves, not in the government, the means to defend their interests. ${ }^{2}$ Besides an insurance program against boycotts and strikes, the proprietors proposed to use the federation to prepare a common plan of action against "the revolutionary syndicalist fury". ${ }^{3}$ To complement this initiative, the landowners in the province of Parma were forming groups of "free workers" to act as strikebreakers and organizing squads of "volunteer workers", composed of sympathizers and young members of the AAP, "to maintain the right to work and take the place of the strikers". ${ }^{4}$ They also began to purchase machinery to replace workers during the harvest. These were significant moves which set a dangerous precedent: the proprietors were prepared to take the law into their own hands to oppose the government's progressive policies in labor conflicts.

In February 1908, the unions in the commune of Noceto began to boycott a proprietor who insisted that his salaried workers without livestock put in thirteen-hour days. The unions, on the contrary, maintained that when a salaried worker did not care for livestock he should put in ten hours like the day laborers. The AAP responded by requiring its members in the commune to sign prornissory notes for the value of the crop (some people said the value of the farm) to guarantee solidarity and by declaring a lockout of all the day laborers in the commune. ${ }^{5}$ The first week in March, it extended the system of promissory notes to all its members. It also ordered the proprietors to enforce a lockout of all the day laborers in the province, to refuse to sign new contracts, and to employ as day laborers only "free workers" with the membership card of one of the company unions. ${ }^{6}$ Within a

${ }^{1}$ La Scintilla, April 11, 1908.

2 Bollettino AAP, January 11, 1908.

3 Ibid., January 2, 1908. See also Bollettino Federale Agrario, August 1-15, 1908.

- Bollettino AAP, February 19, 1908.

s L'Idea, February 22, 1908.

- Bollettino AAP, March 7, 1908. 
month, the president of the AAP announced that various industries, such as the brick factories, which employed many rural laborers, had adhered to the lockout. ${ }^{1}$ At this stage, the salaried workers and sharecroppers were not affected by it.

The chamber of labor, which intended to act in stages, did not initiate a counteroffensive at once. Late in March, its representatives invited each proprietor to respect the provisions of the contract of 1907 , as interpreted by the unions, and threatened to present demands for higher wages to everyone who had not complied by April 15, 1908. Although the union leaders knew that most landowners would not accept this invitation, they wanted to gain enough time to prepare a general strike at the most favorable moment for the workers: the grain harvest in May-June. ${ }^{2}$ Commenting on these decisions, the organ of the chamber of labor concluded in an apocalyptic tone:

"We have accepted the challenge: You wish a duel to the death?

So be it! One of the contending forces must be annihilated." 3

The AAP, on the other hand, was no less eager for battle:

"It's time to say enough. It's time once and for all to test our strength, to let our adversaries know the danger they run every time they provoke agitations, violence and arrogant actions."4

If intransigent language is an accurate indication of the state of mind of both parties, the agitation was beginning in unfortunate circumstances. With such high emotions and the rejection of compromise, a settlement would become difficult. The proprietors, who had the possibility to draw on immense reserves of money and solidarity in the region, were in a strong position. Despite the propaganda of the chamber of labor, the working class, split into antagonistic currents, would not be able to win an easy victory this time.

\section{III}

On May 1, 1908, the chamber of labor proclaimed a general strike in agriculture without a time limit in twenty of the fifty communes of the province. On the plain, where the unions were strong, the agrarian proletariat adhered en masse to the agitation. In the hills, where there were many peasant proprietors, the unions had no influence, and this area took no part in the strike. Although the chamber of labor ordered

Ibid., April 2, 1908.

2 L'Internazionale, March 7 and 28, 1908.

${ }^{3}$ Ibid., March 28, 1908.

4 Bollettino AAP, April 18, 1908 


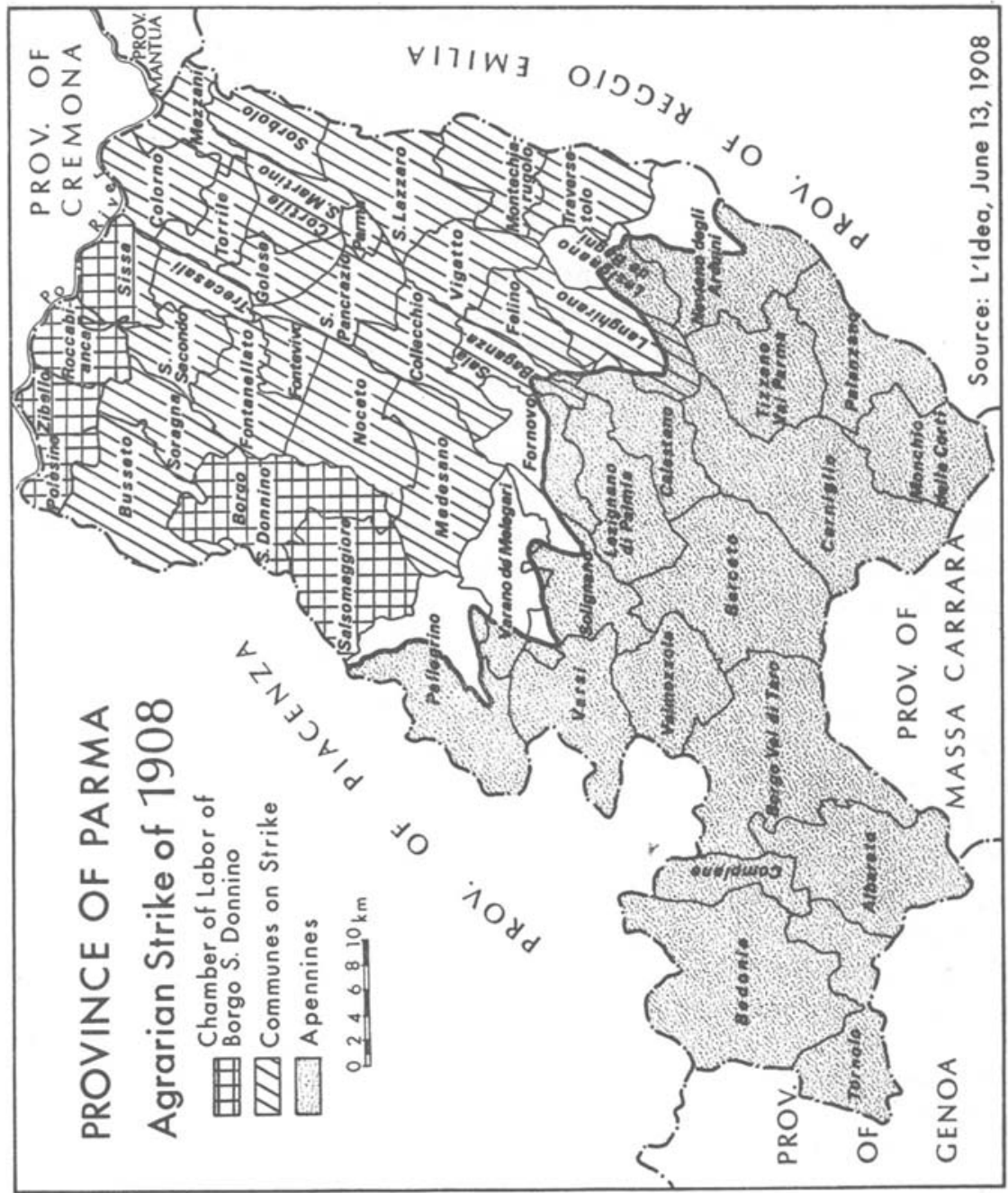

the day laborers and salaried workers to cease work at once, it allowed the stable hands to continue caring for the livestock of landowners who had not adhered to the lockout or violated the contract. Instructing the sharecroppers to abandon the fields for three days in solidarity, it permitted them, too, to care for their livestock. ${ }^{1}$ The immediate aims of the strike were to compel the proprietors to respect the contract of 1907, with slight increases in wages. The long-term

${ }^{1}$ L'Internazionale, Supplemento No 1, May 3, 1908. 
aims were to discredit the AAP and strengthen the union movement in the province.

Although the reformist chamber of labor in Borgo San Donnino, which dominated five communes in the province, did not adhere to the agitation, it pledged to impede the recruitment and passage of strikebreakers. By this benevolent neutrality, the reformists intended to demonstrate their disagreement with the revolutionary syndicalists' strategy and tactics. For them, a strike was "a grievous necessity to which we must have recourse as an extrema ratio; but it is not a normal means of struggle." They charged, on the contrary, that "the revolutionary-syndicalist theory of continuous tension of working-class energy, to be maintained by means of the strike for the sake of the strike, deviates from the ends that our socialist action proposes." 1 It was a reasonable presentation of the reformist socialist position, but it did not demonstrate which strategy would be most effective in winning economic advantages, developing a class consciousness in the workers, and strengthening the unions. And success in these areas would seem to be the test of any course of action in this era.

Within a short time, there were some 20,000 day laborers and salaried workers on strike in twenty-four communes on the plain of the province. ${ }^{2}$ In this tense situation, the prefect declared that he was determined to defend the right to work, prevent outbreaks of violence, and maintain a rigid neutrality between the two parties. To carry out this policy, he immediately concentrated army units in key areas and banned public meetings. ${ }^{3}$ During the same period, the PSI invited its sections to contribute funds, and suggested that the Federterra (National Federation of Land Workers) propose arbitration. ${ }^{4}$ Although the CGL also advocated arbitration, the Federterra replied on May 12 that the proposal was inopportune. ${ }^{5}$ It was a prudent decision. Every piece of evidence indicates that neither the proprietors nor the workers were prepared to accept arbitration so early in the strike. ${ }^{6}$ The AAP was especially intransigent and vindictive. Referring to the revolutionary syndicalists, its bulletin predicted that once "this minority of meddling rogues, $[\ldots]$ who have vilely betrayed the workers' interests

1 L'Idea, April 25, 1908.

2 L'Idea, June 13, 1908; Basevi, "Lo sciopero agrario", p. 145.

${ }^{3}$ Corriere della Sera, May 3, 1908.

- Il Giornale d'Italia, May 7, 1908.

- La Confederazione del Lavoro, May 9 and 16, 1908.

- For the pessimistic opinion of the president of the Parmesan Chamber of Commerce, see Bollettino della Camera di Commercio ed Arti di Parma, XL (May, 1908). For the unions' rejection of the suggestion, see L'Internazionale, May 14, 1908. 
by pushing them into an insane struggle", were out of the way, the proletariat would discover that the proprietors were ready to negotiate. ${ }^{1}$

Defying the prefect's warnings, the strikers tried to prevent the arrival of strikebreakers and exodus of livestock in the early days; for if the proprietors succeeded in sending their cattle out of the strike zone, where the livestock could be boarded or sold, they would be in a much stronger position to resist the unions' demands. The strikers, who were determined to defeat this move, clashed repeatedly with the police and "volunteer workers" on these occasions. The women were particularly active. They slept alongside the dusty roads and on bridges to keep watch. Sometimes they lay down on the roads to prevent the passage of livestock and cavalry. ${ }^{2}$ To bolster the struggle and protect the women, the chamber of labor had planned to enroll squads of union members to fight the "volunteer workers". On May 4, however, it changed tactics: the agitation committee instructed the strikers to allow the departure of the livestock. It stated: "A pure and simple, calm abstention from work, not tumults, will give us victory."3

The revolutionary-syndicalist leadership, the large number of strikers, and the tension in the province were attracting an immense amount of interest in the agitation. Most observers in the first month, above all among reformist socialists, commented that it had the same method and aims as an ordinary economic strike. ${ }^{4}$ Filippo Turati, an implacable enemy of the revolutionary syndicalists, was one of the few to disagree. Asking whether 'the peasants' organizations, pushing or letting themselves be dragged into such an ardent struggle without quarter or remission, are acting in the interests of the proletariat, democracy and the country", he replied that obtaining advantages by these means was "like burning the house to cook an egg". ${ }^{5}$ He was, however, too pessimistic. Although the proprietors' intransigence presaged a long struggle, the possibility of a compromise settlement through the prefect's intervention was not impossible. Despite the revolutionary syndicalists' suspicion of mediation, they would have accepted it, as in the past, in an emergency.

Many revolutionary syndicalists argued that the strike was unique.

1 Bollettino AAP, May 5, 1908.

${ }^{2}$ Corriere della Sera, May 5, 1908.

${ }^{3}$ Ibid.

"L'Idea, May 16, 1908; Adolfo Zerboglio, “Lo sciopero di Parma”, in: Rassegna Contemporanea, I (1908), pp. 598-601; Roberto Forges Davanzati, "Cronaca delle agitazioni popolari: Pedagogia vecchia e nuova del conflitto di Parma", in: Rassegna Contemporanea, I (1908), p. 647.

s Corriere della Sera, May 8, 1908. For the pessimistic predictions of another reformist socialist, see Fausto Pagliari to Rinaldo Rigola, May 6 and 13, 1908, Fondo Rigola (1908), Istituto Giangiacomo Feltrinelli, Milan. 
A writer in $I l$ Divenire Sociale claimed that the workers' determination to act alone, rejecting the assistance of deputies and mediation of government authorities, demonstrated the irreparable divorce between revolutionary-syndicalist direct action and reformist dependence on state intervention. ${ }^{1}$ Others stressed the energy, cohesion and persistence of the workers, along with their willingness to sacrifice, fight and triumph, as notable aspects of the revolutionary-syndicalist heroic spirit. They attributed these characteristics to the propaganda of the chamber of labor. ${ }^{2}$ Paolo Mantica noted that the extension of the strike to as wide an area and to as many categories of workers as possible was a revolutionary-syndicalist tactic. He claimed, with reason, that the reformists preferred to restrict strikes to small areas, such as one commune, and to single categories of workers. ${ }^{3}$

Enrico Leone, the intellectual leader of the revolutionary-syndicalist movement, presented a more cautious interpretation. He stated that in a strict sense "It is like all class manifestations: it is an economic agitation, nothing differentiates it from all the other strikes that have begun, continued and concluded with a settlement in time." $\mathrm{He}$ explained that its notoriety was due to two reasons. First, its "vigorous and emphatic nature" set the strike apart. He attributed these characteristics to "the mature class consciousness of the Parmesan agricultural proletariat, which in a decade of struggles has learned to manage its own affairs and conduct an economic battle of magnificent strength and discipline". Disagreeing with some revolutionary syndicalists, he did not believe that "a group of leaders anxious to attempt a decisive experiment of their doctrine and method" had produced this state of mind. Second, he observed that the landowners' attitude - that is, their vindictive actions - had increased the workers' intransigence. ${ }^{4} \mathrm{He}$ might have mentioned, too, that the workers' victories in 1907 , combined with the propaganda of the chamber of labor, were the main causes of the AAP's combativeness. The revolutionary syndicalists believed, in fact, that both the proletariat and the bourgeoisie must possess a combative spirit for the class struggle to progress.

With the premise that the strike was an experiment in direct action, the revolutionary syndicalists proceeded to explain its significance for the working class. Through a series of strikes, each one more bellicose

1 f.p., "La quindicina: La grande lotta nel parmense", in : Il Divenire Sociale, IV (1908), p. 167.

2 Paolo Orano, "I risultati di un grande sciopero", loc. cit.; L'Internazionale, May 30, 1908.

3 Paolo Mantica, "Mentre a Parma si sciopera", in: La Cultura Socialista, I, pp. 153-55.

4 I1 Nuovo Giornale (Florence), May 10, 1908. 
and extensive, Paolo Orano predicted that the proletariat would develop strength, energy and a mature capacity of resistance. The workers would advance, in this fashion, towards the ultimate aims: "the reduction to a minimum of the proprietors' resistance and the state's disappearance through atrophy of its organs". ${ }^{1}$ Angelo Oliviero Olivetti stated: "It is the acknowledgment of the class struggle, fought with suitable weapons, by both sides." He emphasized that the strike was revealing the true nature of the bourgeois state: "The state limits itself to defense of the law. But this law is a bourgeois law."2 Although it was not a new theme, he wanted to put the workers on guard against the government's pledges to maintain an absolute neutrality in conflicts between capital and labor. Noting that the agricultural workers were assuming an important role in many strikes, Olivetti predicted that the countryside might become "the battleground of the most classic revolutionary struggle fought up to now". ${ }^{3}$

It was a notable insight: the support of the agrarian proletariat would no doubt be indispensable in any revolution. Most revolutionary syndicalists, nonetheless, did not see much validity in the thesis. Arturo Labriola, for example, was pessimistic about the revolutionary capacities of agricultural workers. ${ }^{4}$ The revolutionary syndicalists in the Parmesan chamber of labor, who were more optimistic, believed that a new era was beginning: "In this epoch, democratic illusions will vanish in the clash of two classes in battle [...]. The class struggle will become an evident and notable reality."5 The strike of Parma, in this interpretation, was the experimentum crucis that was bringing about a passage from theory to practice in two areas: the class struggle and the demise of parliamentary socialism. It was not, however, a revolutionary battle. It was the introductory phase of a long struggle. The chamber of labor, which intended to win the strike, not to go down to defeat in a blaze of revolutionary glory, maintained this moderate position throughout the agitation. ${ }^{6}$

In the meantime, the strike continued without any change in strategy. Since the proprietors, however, would not agree to a settlement, the chamber of labor began to consider extending it to some

1 Orano, "I risultati", loc. cit., p. 140. See also L'Azione Diretta (Florence), May 23, 1908.

"A. O. Olivetti, "Anima nuova: A proposito dello sciopero di Parma", in: Pagine Libere, II, pp. 512-13. This article was dated May 17, 1908.

${ }^{3}$ Ibid., pp. 505-07.

4 La Propaganda (Naples), April 20, 1902. See also Dora Marucco, Arturo Labriola e il sindacalismo rivoluzionario in Italia (Turin, 1970), pp. 155-56, 188-90.

5 L'Internazionale, May 23, 1908.

- Ibid., June 13, 1908. 
neighboring provinces, to the region, and throughout the Po Valley. ${ }^{1}$ As part of this plan, it sent strikers' children to board with sympathetic families throughout Northern Italy. ${ }^{2}$ Although this was a maudlin means of winning support and collecting funds for the strike, it may have had some success. Responding to the appeal of the Parmesan workers, the revolutionary-syndicalist leadership of the chamber of labor in Piacenza proclaimed a general strike of solidarity in the countryside on May 17. Without adequate preparation, it was a fiasco. Six days later, the strike committee in Parma, which had taken over its direction, suspended the agitation. In the same period, the chamber of labor in Ferrara, though weakened by the defeat of an important strike in 1907, offered to declare a solidarity strike. The strike committee rejected the proposal. ${ }^{3}$ The revolutionary syndicalists simply did not have the strength and support to expand the agitation beyond the province of Parma.

They decided, therefore, to intensify it in the province by prohibiting the sharecroppers from working in the fields and requesting the adherence of the chamber of labor in Borgo San Donnino.4 Many sharecroppers, however, went into the fields at night to perform indispensable work. ${ }^{5}$ The reformists in Borgo San Donnino, noting that work in the fields was well advanced, voted to boycott "the few proprietors who had accepted livestock from the area of the strike". 6 Confronted with this lack of cooperation, the strike committee decided to allow the sharecroppers to resume work and permit strikers participating in profit-sharing plans to work on May 29-30 and June 2-3.7 Although these vacillations seemed signs of confusion, dissension and weakness in the unions, the decision to permit some categories to return to work may also have indicated a willingness to compromise with the landowners.

In this climate, the authorities began to encourage both parties to come to the bargaining table. Accepting the invitation, the chamber of labor announced that it was ready to negotiate on the basis of the platform adopted at the beginning of the strike. ${ }^{8}$ Through the media-

1 Corriere della Sera, May 24, 1908.

2 Ibid., May 20, 1908; Archivio Centrale dello Stato, Ministero dell'Interno, Direzione Generale di Pubblica Sicurezza, Fondo Gabinetto, Ufficio Cifra e Telegrammi, VIII, No 11815, May 28, 1908 (Milan), pp. 147-48.

${ }^{3}$ Corriere della Sera, May 24, 1908.

4 L'Internazionale, Supplemento No 22, May 25, 1908.

5 Riguzzi, Sindacalismo e riformismo, p. 126.

${ }^{6}$ L'Internazionale, Supplemento No 26, May 29, 1908.

7 Corriere della Sera, May 28, 1908.

${ }^{8}$ L'Internazionale, Supplemento No 32, June 4, 1908. 
tion of the mayor of Parma, the landowners, with some reluctance, also agreed to open discussions. ${ }^{1}$ The differences between the two positions, however, were enormous. To break the deadlock, the mayor presented a set of compromises on wages and hours, with arbitration of the most serious disagreements. ${ }^{2}$ Following the recommendation of Alceste De Ambris, the delegates of the unions, who represented the agrarian workers of twenty-four communes, rejected it. The strike committee, however, passed a motion to re-open discussions if the mayor or the landowners would present more conciliatory proposals. ${ }^{3}$ On the advice of president Lino Carrara, the general council of the AAP accepted the compromise with reservations on two clauses. ${ }^{4}$ This action caused such an uproar of protest among the members, unable to comprehend their leaders' subtle tactics, that the president submitted his resignation - but the directorate refused to accept it. ${ }^{5}$

As a result of the contradictory replies, the mayor announced on June 12 that he would not reconvene the conference for the time being. ${ }^{6}$ The stumbling block was not, in fact, the economic issues that he had attempted to resolve with his compromise. This had become a political strike. Both sides were fighting a desperate battle to determine whether the proletariat or the bourgeoisie would dominate the socioeconomic life of the province. In these circumstances, the acceptance of arbitration by either the chamber of labor or the AAP, which meant recognition of a stalemate, was equivalent to a defeat. By calling a second great strike within twelve months, the revolutionary syndicalists had taken a tremendous risk. To make the workers' sacrifices seem worthwhile, they had to win.

On June 18, the news spread throughout the city that a special train of strikebreakers would arrive the next day in Parma. It produced immense satisfaction among the landowners and dismay among the workers. The rumor that the train would be escorted by a group of "volunteer workers" increased the strikers' resentment and rage. In this atmosphere, representatives of the chamber of labor distributed an incendiary leaflet on the morning of June 19:

"Workers! This morning at 9:42 seven hundred scabs hired by the agrarian association will arrive in Parma. They are coming to take the bread out of the mouths of our children, to starve, to murder our poor peasants who have been fighting for more than

1 Corriere della Sera, June 7, 1908.

2 Ibid., June 9, 1908.

3 Il Nuovo Giornale, June 11, 1908.

- Bollettino AAP, June 13, 1908.

5 Ibid.

- Il Nuovo Giornale, June 12, 1908. 
100 days. Will you allow such an infamy to take place? Will you permit this barbarity, guided and bought by slave-driving feudal lords, the gentlemen of the agrarian association? We do not believe it. No matter what the cost, the working class of Parma will never present such a spectacle of cowardice.

Everyone must stop work and be at the station this morning at 9:30. The scabs absolutely must not enter the Foro Boario [cattle market].It is the demand of civilization, of mothers, deprived of their children, who beg and beseech you, oh brethren of generous Parma.

Remember: Everyone, everyone at the station with a single cry. Get out of Parma, scabs! Get out of Parma!"1

It was an obvious attempt, without any prudence whatsoever, to inflame the striking agrarian workers and the urban proletariat. ${ }^{2} \mathrm{~A}$ clash had become inevitable.

When the train arrived, 380 strikebreakers got out and proceeded through the station with a massive police escort. Meanwhile, the authorities were trying to clear the large square in front of the station by use of cavalry. With women workers lying down on the pavement to prevent the horses' passage, there were violent clashes as the troops, supported at times by "volunteer workers", tried to push the crowd into the adjoining streets. Although they succeeded, riots soon exploded in the center of the city. The scuffles continued for most of the day. ${ }^{3}$

That evening, some 3,000-4,000 workers gathered in the courtyard of the chamber of labor to assess the course of events: the clashes had produced a definite radicalization of their mood. Alceste De Ambris declared that "in the province of Parma there no longer exists any law, only the arbitrary acts of a band of thieves in the agrarian association to whom the authorities have abdicated". The workers voted to call a general strike throughout the province without a time limit "to bring about the re-establishment of the rule of law". They invited the Italian proletariat to be ready to prevent new acts of violence by the state. ${ }^{4}$ In the meantime, residents of the Oltretorrente, the workingclass district across the river from the center of town, began to prepare for battle by carrying cobblestones and crockery onto the roofs.

1 Ibid., June 20, 1908.

2 Alceste De Ambris, who had been out of town at the time, stated afterward that the leaflet had violated his instructions to avoid a confrontation. L'Internazionale, April 19, 1913. Ex post facto evidence of this nature, however, is inconclusive.

${ }^{3}$ L'Internazionale, Supplemento, No 42, June 20, 1908.

4 Ibid. 
On June 20, the organ of the chamber of labor wrote: "The entire Po Valley is in agitation, shaken by a strong wind of energy and revolt. [...] In the future, the revolutionary proletariat of Parma, of the Po Valley and throughout Italy may be with us to enlarge the base of the battle." 1 A second article, entitled La rivolta, concluded with the phrase: "The government authorities may ignite the explosives! Forward!"2 Despite the violent language, the aim was to force the government to return to a position of relative neutrality and allow the working class to continue the strike without the menace of mass arrests. With the precedents of general strikes in 1904, 1906 and 1907, the authorities could not afford to ignore the likelihood of a fourth nation-wide protest. It was a delicate moment.

As groups of workers crowded the narrow lanes of the Oltretorrente that morning to discuss the events of the previous day, squads of strikers began to cross the bridge. Aiming to close any shop that might have remained open, they advanced towards the main square and clashed almost at once with some "volunteer workers". Intervening to restore order, troops pushed the strikers back across the bridge; and, in a hail of stones from the roof tops, infantry and cavalry proceeded through the streets to the headquarters of the chamber of labor. At that point, the police broke down the door, invaded the building, arrested members of the strike committee and executive committee of the organization in the midst of a meeting, and confiscated documents and money. ${ }^{3}$ Alceste De Ambris and Tullio Masotti, the secretary and vice-secretary of the chamber of labor, were absent and escaped arrest. In the space of a morning, the authorities had decimated the cadres of the unions through mass arrests and occupied the headquarters of the chamber of labor. ${ }^{4}$ Only

1 Ibid.

Ibid.

3 Il Nuovo Giornale, June 21, 1908.

4 Although the magistracy instituted proceedings against 160 persons, only 7 were brought to trial. The charges were criminal association to commit offenses against persons and property, with Alceste De Ambris as head of the association (Penal Code, Art. 248); commission of acts to bring about an armed uprising against the powers of the state, with Alceste De Ambris as the leader (Art. 120); and moral complicity in 12 cases of unsuccessful homicide (Art. 364, 365 (2), 62, 63). In a decision on May 10, 1909, the Court of Assize in Lucca found the defendents not guilty on these charges. It condemned Alceste De Ambris to a one-year prison term, with a six-month reduction, on the charge of injuring a policeman with intent ("lesione aggravata", Art. 372 (1) and 373). It sentenced Giovanni Pizzarotti, managing editor of L'Internazionale, to nine months in prison and a 300 lire fine on charges of justification of a crime, instigation to disobey the law, and instigation of hatred among social classes in a manner to endanger public peace (Art. 247). In this case, it granted an amnesty that freed 
towards evening, some modicum of peace came to the city. Commenting on these incidents, Prime Minister Giovanni Giolitti stated that the government had acted to maintain public order. Citing the arrest of some members of the AAP, who had been carrying arms in public, he reiterated his determination to take measures against anyone, without exception, who threatened law and order. ${ }^{1}$

On June 21, scuffles that pitted strikers against "volunteer workers" and troops continued in various parts of the city. In this tense situation, there were two tactics to end the occupation of the chamber of labor: negotiations with the authorities or a nation-wide general strike. $^{2}$ The revolutionary syndicalists favored a strike. The reformist socialists, led by a group of PSI deputies, opened discussions with the prefect. As the chambers of labor replied to the call for a general strike, it soon became evident that they were not prepared to support such an action. ${ }^{3}$ With the exception of the province of Parma, therefore, the general strike was a failure. ${ }^{4}$ The PSI deputies' negotiations, on the contrary, were producing concrete results: on June 24, the authorities returned the headquarters of the chamber of labor to representatives of the unions and the street fighting ceased altogether. ${ }^{5}$ The strike committee, in response, authorized the proletariat of the city to return to work the following day. When the workers showed up at their jobs, however, they learned that the proprietors had declared a five-day lockout. ${ }^{6}$ Although this action was an obvious challenge to the authority and prestige of the unions, the strike committee decided not to resist it.

Despite the unfortunate turn of events, the revolutionary-syndicalist press hailed the return of the headquarters of the chamber of labor as

him at once. Archivo Centrale dello Stato, Ministero di Grazia e Giustizia, Direzione Generale di Affari Penali, 1909, Busta 120, Fascicolo 160, "Corte d'Assise di Lucca: Sentenza Penale: Processo per i fatti di Parma, 10 maggio, 1909".

1 Atti del Parlamento Italiano, Camera dei Deputati, Sessione 1904-08, Discussioni, I Tornata del 20 giugno, 1908, XIX (Rome, 1908), p. 23141. The authorities, in fact, did not welcome the assistance of the "volunteer workers". See Archivio Centrale dello Stato, Ministero dell'Interno, Direzione Generale di Pubblica Sicurezza, Fondo Gabinetto, Ufficio Cifra e Telegrammi, VIII, No 12222, June 2, 1908 (Parma), p. 276.

2 Il Nuovo Giornale, June 22, 23 and 24, 1908.

${ }^{3}$ Avanti!, June 27, 1908.

4 Archivio Centrale dello Stato, Ministero dell'Interno, Direzione Generale di Pubblica Sicurezza, Fondo Gabinetto, Ufficio Cifra e Telegrammi, X, No 14486, June 25, 1908 (Genoa), p. 13; No 14489, June 25, 1908 (Leghorn), p. 14; No 14543, June 25, 1908 (Ancona), p. 31.

- La Confederazione del Lavoro, June 27, 1908; Il Nuovo Giornale, June 24,1908.

- Avanti!, June 26, 1908. 
a great victory of direct action. La Guerra Sociale in Turin wrote: "The general strike of Parma had ended. The government has given in to the revolutionary pressure of the working class." ${ }^{1}$ It might have been more accurate to conclude, as Arturo Labriola admitted two years later, that only the PSI deputies' intervention had avoided the dissolution of the chamber of labor. ${ }^{2}$ At most, the pressure of the riots in Parma and the menace of a general strike in the nation had played a collateral role in the authorities' decision to grant the deputies' request.

In the midst of the riots, Alceste De Ambris and Tullio Masotti had escaped to Switzerland. The flight of these charismatic condottieri of the working class caused considerable controversy. Many people, friends and foes, believed that they should have remained to share the fate of the workers. Continuing to urge resistance from abroad, De Ambris stated that with the grain harvest at its height, a last effort by the strikers might be sufficient to win some sort of victory over the beleaguered proprietors, anxious not to lose a good part of the crop. ${ }^{3}$ Defining the strike as "a state of permanent revolution", Masotti envisaged it as a means to undermine the principles of authority and property. ${ }^{4} \mathrm{He}$ predicted that "the proletariat will see its strength and revolutionary capacity increase, even if it will not attain - to the serious scandal of the reformist shopkeepers - a wage hike of a few centesimi."5

The exiles, however, had misjudged the temperament of the agricultural workers and the chances that the strike might still succeed. The imprisonment and flight of key leaders, the completion of the grain harvest by machinery, renegade union members and strikebreakers, and the mass desertions of salaried workers were bringing the agitation to an end in many areas of the province. Writing on July 4, the prefect reported that the strike had become more nominal than effective. When two squadrons of cavalry and one battalion of infantry departed five days afterward, it was evident that the authorities considered the menace of serious incidents to be over. ${ }^{6}$ Announcing the end of the lockout on July 25, the AAP allowed its members to hire day laborers on the terms of the contract of $1907 .{ }^{7}$ The majority

1 La Guerra Sociale, June 27, 1908.

2 Il Grido degli Oppressi (Terni), December 17, 1910.

3 L'Internazionale, June 28, 1908.

- Ibid., Supplemento No 56, July 12, 1908.

B Ibid., Supplemento No 63, July 20, 1908

- Archivio Centrale dello Stato, Ministero dell'Interno, Direzione Generale di Pubblica Sicurrezza, Fondo Gabinetto, Ufficio Cifra e Telegrammi, X, No 15461, July 4, 1908 (Parma), p. 316; No 15949, July 10, 1908 (Parma), p. 467.

7 Bollettino AAP, August 8, 1908. 
of the salaried workers had already returned to their jobs. They had to give up membership in the chamber of labor, accept the card of a "free worker" in a company union, and promise not to strike before November 11, 1908 (they deposited 20 per cent of each day's wages as a guarantee). The proprietors evicted any salaried worker who refused to agree to these conditions. ${ }^{1}$ Although the chamber of labor continued to urge the workers to resist, the agitation - in the sense of an active strike - was simply petering out.

Responding to the dissatisfaction and aspirations of the day laborers in capitalistic agriculture, the revolutionary syndicalists had constructed a strong base in the province of Parma. By organization and propaganda, assisted by the victories of 1907 , they developed the capacities of resistance and heightened the class consciousness of the agrarian proletariat. They made many agricultural workers aware that the union could be an effective organization to defend their interests. They widened, in the process, the gap between the proletariat and the bourgeoisie in the countryside. They argued, with reason, that too many compromises with the bourgeoisie hindered the formation of an intransigent, combative spirit and revolutionary tension in the working class. The revolutionary syndicalists, however, failed to formulate a viable alternative to the reformist strategy of cooperation.

The revolutionary syndicalists' concept of the class struggle, in fact, was the main cause of the defeat of the strike. They were determined to challenge the landowners again. Their refusal to nominate representatives to the arbitration commission, announcement of the strike six months in advance, and inflammatory propaganda gave the AAP time to prepare an offensive. These moves also alarmed moderates in the working class. Once the strike began, its leaders neglected to persuade the peasant proprietors and tenant farmers to maintain a benevolent neutrality; nor did they give the sharecroppers any reason to offer more than token aid. They believed that these intermediate categories, who were attached to the concept of private property, must eventually decline to the status of day laborers to develop a class consciousness.

Nor did the revolutionary syndicalists really try to win support for the strike among reformists in the unions and the PSI. Although they asked the reformist socialists, who controlled the chamber of labor in Borgo San Donnino, to adhere to the agitation, they continued to stress its revolutionary-syndicalist nature. The reformists, who were

1 L'Idea, August 1, 1908. 
combatting this theory and practice, naturally rejected the invitation. Since a revolutionary-syndicalist congress had voted in 1907 to abandon the PSI, the party limited its assistance in the weeks before the crisis of June 19-24 to a fund drive. The Federterra and the CGL, whose reformist policies were the cause of a revolutionary-syndicalist boycott, did the same. Their attitude was justifiable. The revolutionary syndicalists vehemently protested when these organizations intervened to aid the striking workers and express an opinion after the riots in the city of Parma.

In some respects, the lack of extensive support for the strike was a positive factor. The homogeneous leadership and the day laborers' dominant role gave it unity, discipline and consistency of purpose. These characteristics aided it to last seven weeks, up to the riots of June 19-24, without serious defections. After the imprisonment and exile of the revolutionary-syndicalist chieftains, however, the workingclass front began to crumble. The salaried workers were the first to admit defeat. With an annual contract that provided job security and an interest in the production, they often had a warm rapport with their employers; they did not usually develop, therefore, the class consciousness and combative spirit of the day laborers. In the same weeks, most women workers deserted the strike and abandoned the unions. ${ }^{1}$ The day laborers were the last to give up. When they did, it is probable that the recent converts, without experience in long strikes, ceded before the veterans.

The revolutionary syndicalists, in sum, had overestimated the agrarian proletariat's strength, consistency and will to fight a long, difficult battle. In case of victory, as in 1907, many agricultural workers would have joined the unions. Writing during the strike, Georges Sorel had predicted that in case of failure the embittered workers, eager for revenge, would remain in the unions to renew the struggle in the future. ${ }^{2}$ The defeat, instead, generated a wave of resentment and suspicion in the working class against the labor movement. Although the revolutionary syndicalists retained a majority in the chamber of labor, its membership dropped from 28,719 on January 1,1908 , to 7,034 on January $1,1909 .^{3}$

Disregarding the evidence, the revolutionary syndicalists had underestimated the landowners' energy, tenacity and determination to crush the unions. The attitude that the proprietors assumed in the strike, practically taking the law into their own hands on some

1 L'Internazionale, November 20, 1909.

2 Ibid., Supplemento No 64, July 21, 1908.

3 Statistica delle organizzazioni di lavoratori al 1 gennaio, 1913, p. 104. 
occasions, was a notable development. The use of "volunteer workers", which represented a lack of confidence in the authorities, and "free workers", grouped in company unions, demonstrated a consciousness of the stakes and a willingness to act that were without precedent in the province. Enrico Leone noted: "The characteristic and new aspect of the strike in Parma is not to be found in the revolutionary-syndicalist ideas of its leaders, but in the new phase of the proprietors' resistance." 1 The sight of two strong forces engaged in a gigantic struggle was indeed a spectacle to enthuse any revolutionary syndicalist. Sorel remarked: "The bourgeoisie seems to have put up a resistance which indicates that it is less apathetic than ours; this is perhaps because the workers' violence has given it a little virility."2

There had been, however, no need of violence to provoke the landowners. "Except for a few stones picked up on the street and thrown from the roofs", commented La Guerra Sociale in Turin, "nothing was done except preach calm." The writer complained that "instead of sowing with both hands the idea and intention of expropriation, the only real goal of a general strike, it was decided to return to work and then accuse the reformists of treachery." 3 Referring to the opinion of "a great master of economics" (probably Vilfredo Pareto), Agostino Lanzillo noted that the revolutionary syndicalists' respect for law, with their rejection of violence to check sabotage by the reformists and the arrogance of the state, were the main causes of the defeat." Alceste De Ambris gave some credence to this critique: "I believed, with the comrades on the strike committee, that it was possible in Italy to conduct a strike. like the one in Parma, with peaceful tactics." 5 The revolutionary syndicalists had not attempted to use violence in the strike. They had tried, nevertheless, to put into practice a strategy of permanent conflict, employing the union "as an instrument of conquest and defense against the proprietors", with a crude set of tactics that did not take into account the strength of the opposition. ${ }^{6}$

The bourgeoisie was strong. The working class, wavering between resignation and rebellion, was weak. The revolutionary syndicalists did not appreciate that the workers, without compromising their long-term aims, had to form alliances with some strata in the bourgeoisie

1 Enrico Leone, "L'atto di accusa contro lo sciopero di Parma: Glossa lineare ad un articolo di L. Bissolati", in: Il Divenire Sociale, IV, p. 284.

${ }^{2}$ Georges Sorel to Paolo Orano, August 16, 1908, loc. cit.

${ }^{3}$ La Guerra Sociale, October 1, 1910.

4 Agostino Lanzillo, Le mouvement ouvrier en Italie (Paris, n.d.), p. 40. See also Sorel to Orano, loc. cit.

5 L'Internazionale, November 24, 1908.

- Ibid., December 24, 1908. 
and develop contacts with the authorities to attain intermediate objectives. The revolutionary syndicalists in the Parmesan chamber of labor, who were aware that government intervention to restore law and order might mean the failure of the strike, wanted to avoid disturbances. Towards mid-June, however, their intransigence in the negotiations, accompanied by a doctrinaire insistence of fighting to the end, was leading the agitation into a blind alley. Searching for any means to bring about a victory, they did not take enough precautions to prevent a confrontation. By that time, they had lost the strike. 